\title{
DEVELOPMENT OF ONLINE MENTAL HEALTH SUPPORTING GROUP TO REDUCE MENTAL BURDEN DURING COVID-19 PANDEMIC
}

\section{PENGEMBANGAN GRUP DUKUNGAN DARING TERHADAP KESEHATAN MENTAL UNTUK MENGURANGI BEBAN MENTAL SELAMA MASA PANDEMI COVID-19}

\author{
Annette d'Arqom', B rihastami Sa witri' ${ }^{2}$, Zamal Nasution ${ }^{3}$, Dimas Setyanto ${ }^{4}$, Safira \\ Nur Izzah ${ }^{4}$, Ludy Diana Wiradhika ${ }^{4}$, Rakha Achmad Maulana ${ }^{4}$ \\ ${ }^{1}$ Department of Pharmacology, Faculty of Medicine, Universitas Airlangga, Indonesia \\ ${ }^{2}$ Department of Psychiatry, Faculty of Medicine, Universitas Airlangga, Indonesia \\ ${ }^{3}$ Graduate program in Institute of Population and Social Research, Mahidol University, \\ Thailand \\ ${ }^{4}$ Faculty of Medicine, Universitas Airlangga, Indonesia \\ email: annette-d-a@ fk.unair.ac.id
}

\begin{abstract}
Abstrak
Pandemi COVID-19 memengaruhi semua aspek kehidupan manusia, tidak hanya kesehatan, tetapi juga ekonomi, pendidikan, dan aktivitas sehari-hari. Perubahan mendadak tersebut menyebabkan beban mental bagi sebagian besar orang. Apalagi, badai informasi bisa menambah beban. Sayangnya, tidak semua orang menyadari beban mental mereka, dan memiliki orang untuk berbagi dan peduli. Oleh karena itu, kelompok pendukung online anonim (www.laluibersama.com) dikembangkan untuk meningkatkan kesadaran akan kesehatan mental dan menyediakan fasilitas untuk berbagi dan mendukung antar pengguna. Situs ini terdiri dari beberapa informasi dasar dan artikel mengenai COVID-19 dengan penekanan pada farmakoterapi dan kesehatan mental, forum berbagi, dan kalkulator kesehatan mental berdasarkan skala depresi, kecemasan, dan stres (DASS 21). Dari evaluasi tersebut, $53.61 \%$ pengguna memilih kalkulator kesehatan mental sebagai halaman favorit, diikuti oleh artikel (29.90\%), homepage (12.37\%), dan halaman berbagi (4.12\%). Sebagian besar responden setuju bahwa kalkulator kesehatan jiwa itu unik dan valid, oleh karena itu dapat digunakan sebagai skrining masalah kesehatan jiwa. Secara keseluruhan kesehatan jiwa perlu mendapat perhatian lebih dalam menghadapi pandemi ini karena beban yang semakin meningkat, dan pemeriksaan dini masalah kesehatan jiwa dan berbagi kekhawatiran dan pemikiran dapat dilakukan di www.lalui bersama.com.
\end{abstract}

Kata kunci: COVID-19, daring, dukungan, kalkulator kesehatan mental

\begin{abstract}
Abs tract
COVID-19 pandemic affects all aspects of human life, not only health, but also economic, education, and daily activity. The sudden changes caused a mental burden for the majority of people. Moreover, the infodemic might increase the burden. Unfortunately, not all people aware of their mental health and with the negative stigma from the community lead the patient to hesitate for sharing and seeking help. Therefore, an anonymous online supporting group (www.laluibersama.com) is developed to increase awareness of mental health and provided the facility to share and to support users. This site consists of several basic information and articles regarding COVID-19, emphas izes on pharmacotherapy and mental health issues, sharing forum,
\end{abstract}


and mental health calculator based on depression, anxiety, and stress scales (DASS 21). From the evaluation, $53.61 \%$ of users choose mental health calculators as the most favorite page, followed by article (29.90\%), homepage (12.37\%), and sharing page (4.12\%). Most of the respondents agree that the mental health calculator is unique and useful, therefore can be used as a screening of mental health problems prior seeking health professional help. Taken together, mental health needs more attention in this pandemic due to the increasing burden, and the screening of mental health problems and sharing to alleviate the burden can be performed at www.lalui bersama.com.

Ke ywords: COVID-19, mental health calculator, online, support

\section{INTRODUCTION}

The COVID-19 outbreak forces everyone to limit activities outside the home and physically distance themselves from others (CDC 2020). To prevent transmission, workplaces and schools are also closed or open with restriction, thus the students and the workers study and work from home (Setkab 2020). Conflict is inevitable because the meetings are intense and without interval. In China as the first country to lockdown, the violence and divorce rate increases during the quarantine period (Zhang 2020). Not only in China, violence and domestic abuse, some related to death, has been reported all over the world (Usher et al. 2020). It might be related to the reduction of household income, the needs that tend to increase, as well as increasing the prices of goods which affects a person's mental health status (Xiong et al. 2020). For individuals who are accustomed to social life, this can affect them, such as excessive anxiety about contracting COVID-19 (Lee et al. 2020). In addition, the infodemic, rapidly spreading of unreliable information about COVID-19, such as the use of herbal or vitamin supplements that have no scientific evidence but disseminated as COVID-19 prevention (Islam et al. 2020). The culture of Indonesians who love to gather and talk is one of the challenges to prevent COVID-19 from spreading in Indonesia (Lukman et al. 2015). The restriction of mass gathering might cause mental health problems to vulnerable individuals (Kar et al. 2020). Unfortunately, awareness of mental health and the negative stigma from the community become a barrier to share and seek for help (Knaak, Mantler, and Szeto 2017). Therefore, this community service tries to develop an online mental health supporting group to reduce the burden of mental health and increase the awareness of this issue. Moreover, mental health calculator is provided for early screening before health professional consultation.

\section{COMMUNITY SER VICES METHODS}

This community service obtained ethical clearance from the Faculty of Medicine, Universitas Airlangga No. 180/EC/KEPK/FKUA/2020. The online mental health supporting group was developed and could be accessed at www.laluibersama.com. This site consisted of several pages which were homepage, articles, sharing, mental health calculator, and contact us. The homepage provided the background of the website development and basic information regarding COVID-19 such as what was COVID-19, how it was spreading, how to prevent from getting infected, and information regarding stigma and negative view regarding COVID-19. The next page was articles that 
provided more detailed information regarding pharmacotherapy and mental health issues during the COVID-19 pandemic.

Furthermore, a sharing forum section allowed users to share, ask, or answer some story or their thought regarding COVID-19. Moreover, the last section was the mental health calculator based on depression, anxiety, and stress scales (DASS 21). Further, the publication of this website was conducted through online meetings with several groups such as parents meeting forums, religious forums, health provider forums, and student forums. The announcement through social media is also performed to increase the usefulness of this website. The evaluation was done by circulated the online questionnaire to the users.

\section{RESULTS AND DISCUSSION}

\section{Online Supporting Group}

The online mental health supporting group can be accessed at www.laluibersama.com. Figure 1 showed the layout and design of the website which consists of a homepage, articles, sharing, and mental health calculator.

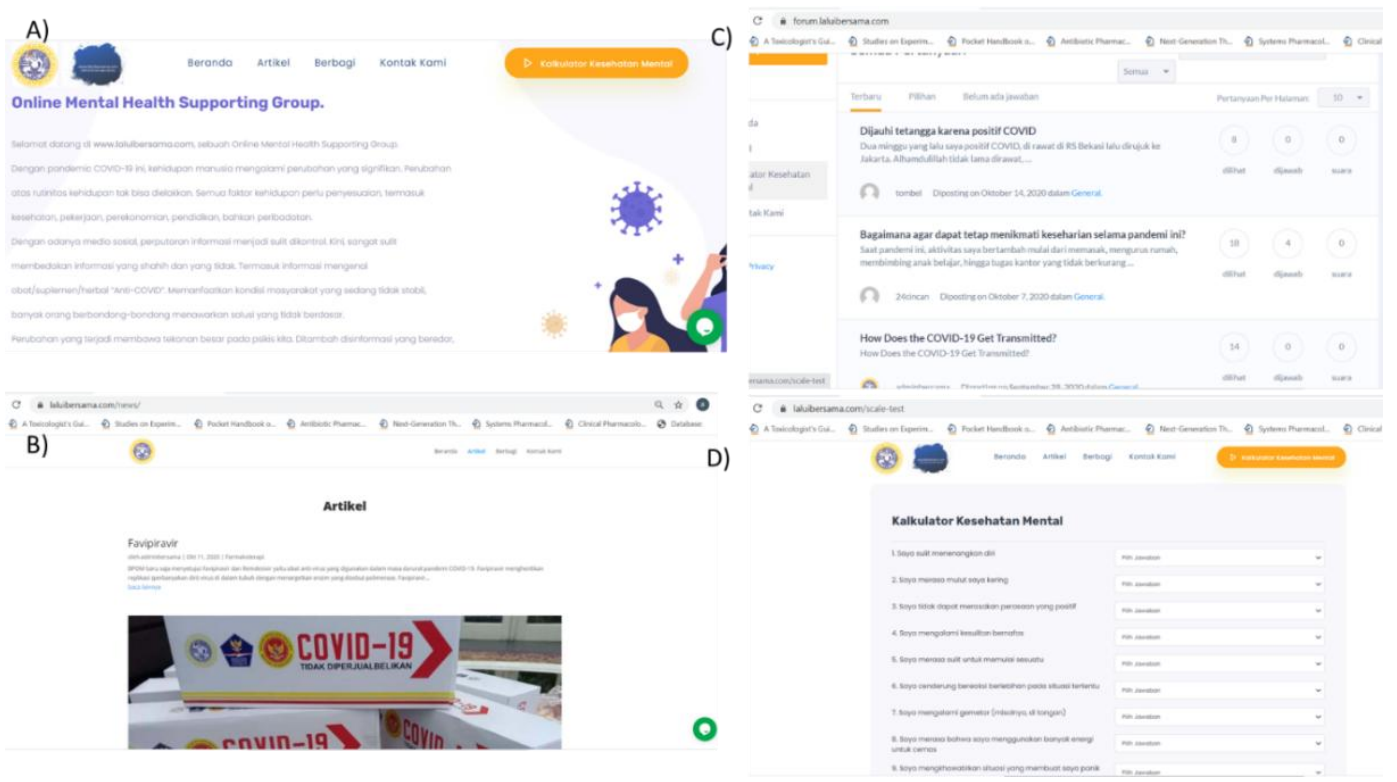

Figure 1. Layout and design of www.laluibersama.com which consists of (A) homepage, (B) articles, (C) sharing forum, and (D) mental health calculator.

Users could access the sharing forum by sign in using their email address, no privacy and identity were provided except alias name and email address. A confirmation link was further sent to the intended email address. The authentication was necessary before accessed the forum. Further, the user can start to ask or reply to the story or thread that has been posted in the forum by clicking the orange button (Figure 2). 
Annette d'Arqom dkk.: Development of Online Mental Health Supporting Group to Reduce Mental Burden During Covid-19 Pandemic

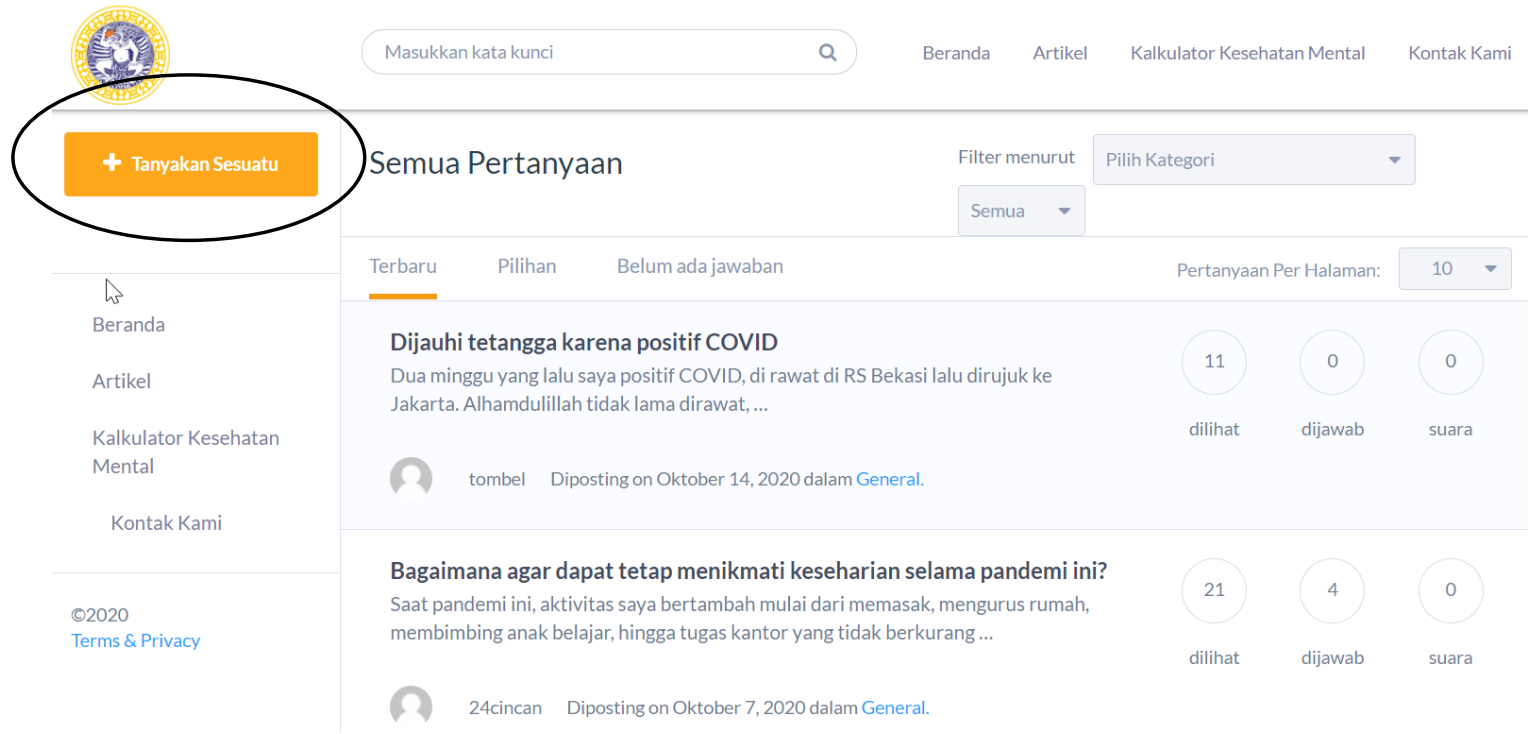

Figure 2. Sharing forum layout. The page can be accessed only by registered users. To make a new question or sharing a new story, the orange button needed to be clicked, whilst to answer the question, the user can click the question.

Moreover, in the mental health calculator, 21 questions derived from DASS 21 were asked with should be answered by choosing 1 of 4 selection which was never, sometimes, often, almost always (Figure 3).

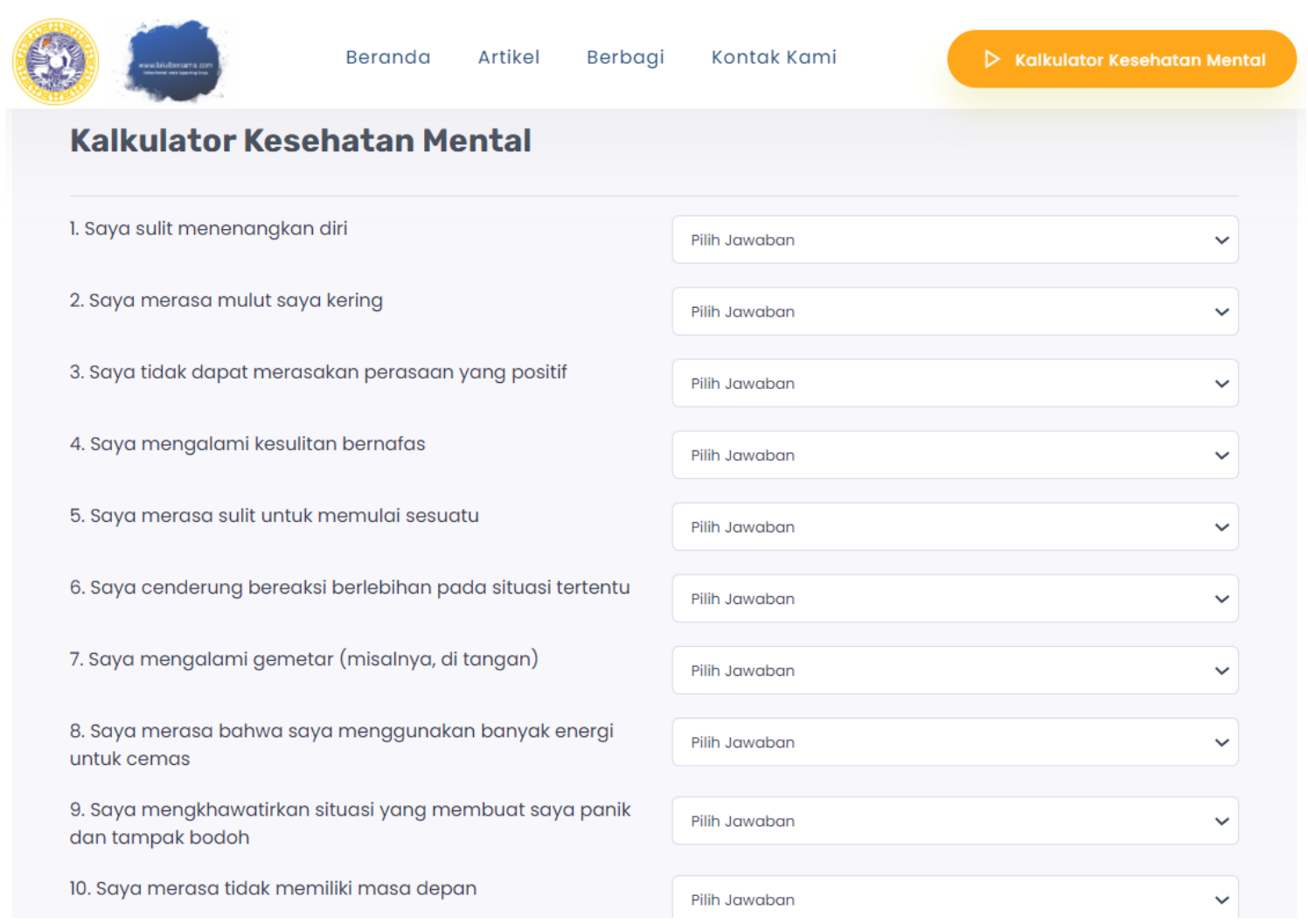




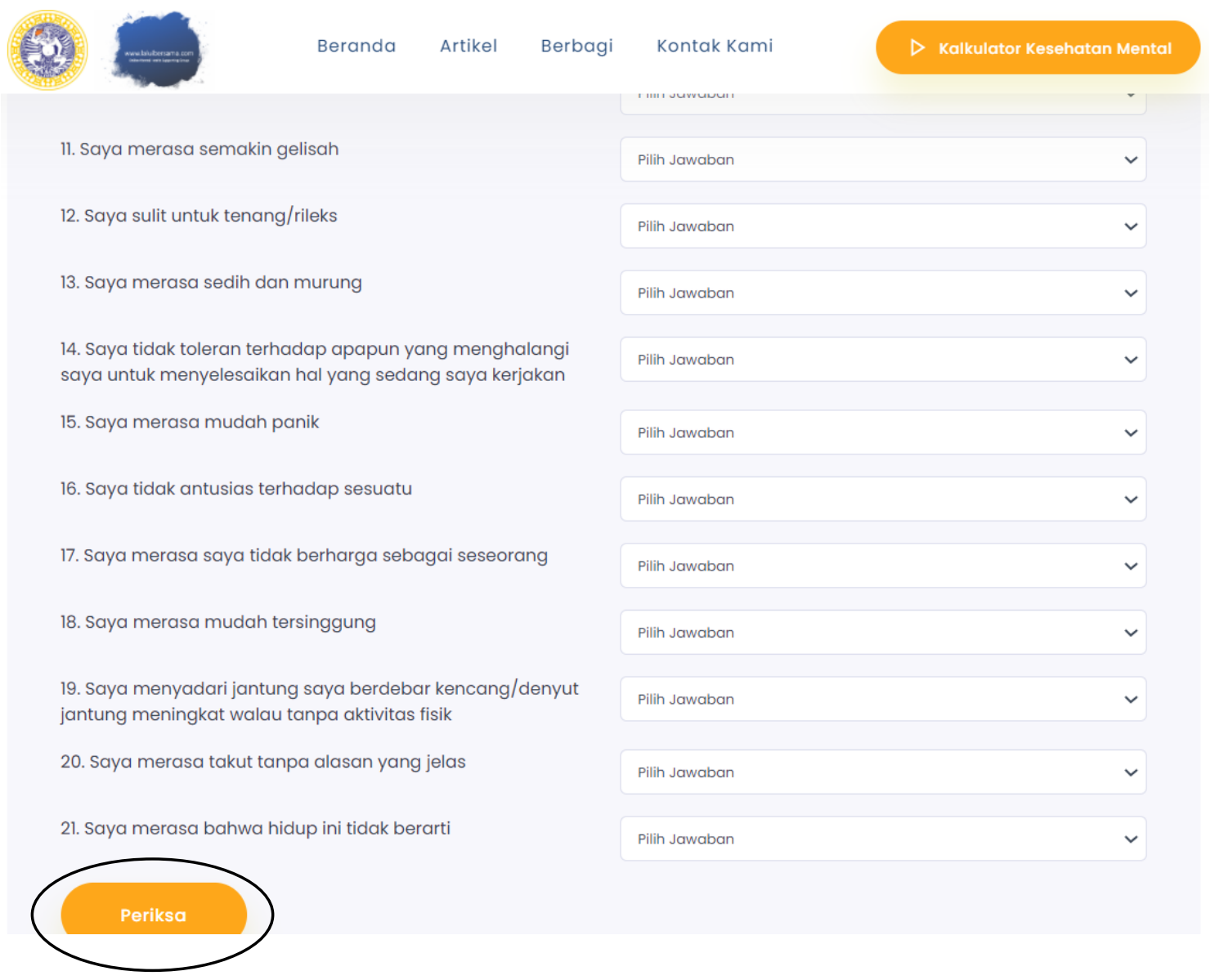

Figure 3. Mental Health Calculator based on Depression, Anxiety, and Stress Scales (DASS 21)

By clicking the orange button "PERIKSA", the calculation started and the score of each classification which was depression, anxiety, and stress were provided including its severity. This page was only for screening, not as a diagnostic. Therefore, users needed to seek health professionals' help.

\section{Characteristics of the users and evaluation from the users}

A total of 102 responses were received, but only 97 questionnaires were valid and used in the final analysis, corresponding to an effectivity rate of $95 \%$. Based on the location, $86.6 \%$ resided in Java island $(n=84)$, and the rest was on another island $(13.4 \%, n=13)$. Majority of users were female $(71.13 \%, n=69)$ and $28.87 \%(n=28)$ were male. Sixtytwo users $(63.92 \%)$ were 18-20 years old, $12(12.37 \%)$ were $>20-30$ years old, 11 $(11.34 \%)$ were $>30-40$ years old, and the rest were 40 years old $(12.37 \%)$. Based on their occupation, $70.1 \%(n=68)$ were students, $2.06 \%(n=2)$ were housewives, $10.31 \%$ $(\mathrm{n}=10)$ were government officers, $11.34 \%(\mathrm{n}=11)$ worked in the private sector, and $6.19 \%(n=6)$ were others such as entrepreneurs or online selling (Table 1). 
Table 1. Characteristics of users

\begin{tabular}{lll}
\hline Characteristic & $\mathbf{N}=\mathbf{9 7}$ & $\mathbf{\%}$ \\
\hline Location & & \\
Java island & 84 & $86.6 \%$ \\
Outside Java & 13 & $13.4 \%$ \\
\hline Gender & & \\
Male & 28 & $28.87 \%$ \\
Female & 69 & $71.13 \%$ \\
\hline Age & & \\
$18-20$ y.o & 62 & $63.92 \%$ \\
$>20-30$ y.o & 12 & $12.37 \%$ \\
$>30-40$ y.o & 11 & $11.34 \%$ \\
$>40$ y.o & 12 & $12.37 \%$ \\
\hline Occupation & & \\
Student & 68 & $70.1 \%$ \\
Housewife & 2 & $2.06 \%$ \\
Govern ment Officer & 10 & $10.31 \%$ \\
Private Sector & 11 & $11.34 \%$ \\
Other & 6 & $6.19 \%$ \\
\hline & &
\end{tabular}

Sixty-one (62.89\%) of the users known www.laluibersama.com from their friends/colleagues, while the rest got the information from social media. Moreover, from the four sections in the website, 53.61\% ( $\mathrm{n}=52)$ favor mental health calculator, followed by articles $(29.9 \%, n=29)$, homepage $(12.37 \%, n=12)$, and sharing $(4.12 \%$, $n=4)$. When the researcher dug more detail about the reason, 36.08\% $(n=35)$ of users agreed that the mental health calculator was useful for early detection of mental health especially during the pandemic that increases the stressor. As mentioned by user \#9 and $\# 13$.

"Because this is the first time I have met this feature here and it has been added that recently a lot of people have been self-diagnosed regarding their mental health before going to the doctor, this is because maybe because they are embarrassed and do not have the cost to check, so with the health calculator mentally, the community does not need to be ashamed and will not be self-diagnosed regarding their mental health."

"I can measure my mental health, because, currently, online lectures make me a little bored and feel stressed and tired more often than if I study offline, the mental health calculator is very interesting in my opinion and very good to be developed continuously, especially during this time."

Moreover, $20.62 \%(n=20)$ found interesting and accurate articles since the infodemic during COVID-19 were confusing, as mentioned by user \#23 and \#6:

"This website contains detailed explanatory information about COVID-19 and its prevention. The language is easily understood and suitable for the general public."

"The articles are very informative and broadening my knowledge. There is so much information outside, and we do not know which one is true." 
Some users $(35.05 \%, \mathrm{n}=34)$ found an interesting interface and layout of the website. As mentioned by user \#43 and \#74:

"This website gives positives vibe during this unknown-end-pandemic."

"It is very eye-catching, especially the homepage. I love the color."

However, some respondents also suggested some improvement, especially to add more interactive content, as mentioned by user \#5 and \#6:

"The narrative is too long and monotone. It can be varied thus it can increase the interest of the reader. Some innovations can be adapted such as online ranking games (with a feature model like a quizzes) related to relevant knowledge or information, thereby increasing user interaction with one another."

"The content on the page is very informative, but it would be better if it is presented with a more attractive web design. In my opinion, the contents are around $85 \%$ words, so visitors tend to be lazy to read the writing. However, if there is a touch of an attractive image and design, maybe more visitors will stop by."

Moreover, users who scored high on the mental health calculator could contact the web admin and advised to seek the nearest health professional help, based on the referral system.

\section{Conclusion}

The developed website has useful content, especially the mental health calculator and articles which might bring advantages for early mental health screening and convey reliable information during the COVID-19 pandemic. Moreover, to increase the usefulness of the sharing forum, improvement and promotion are necessary. To attract more users, improvements in the content, interface, and layout are important. An interactive feature is necessary to invite more visitors. This website can be applied in many sectors, including screening of student's mental health and encourage the student to share his/her burden, anonymously.

\section{Acknowledgments}

This study was funded by RKAT Institute of Research and Innovation Universitas Airlangga No. 1082/UN3.14/PT/2020. 


\section{REFERENCES}

CDC. 2020. "Social Distancing." CDC. Accessed 1 November, 2020. Retrieved from: https://www.cdc.gov/coronavirus/2019-ncov/prevent-getting-sick/socialdistancing.html.

Islam, Md Saiful, Tonmoy Sarkar, et al. 2020. "Covid-19-Related Infodemic and Its Impact on Public Health: A Global Social Media Analysis." The American Journal of Tropical Medicine and Hygiene 103, no. 4: 1621-1629. https://dx.doi.org/https://doi.org/10.4269/ajtmh.20-0812.

Kar, Sujita Kumar, S. M. Yasir Arafat, et al. 2020. "Coping with Mental Health Challenges During Covid-19." In Coronavirus Disease 2019 (Covid-19): Epidemiology, Pathogenesis, Diagnosis, and Therapeutics, edited by Shailendra K. Saxena, 199-213. Singapore: Springer Singapore.

Knaak, Stephanie, Ed Mantler, et al. 2017. "Mental Illness-Related Stigma in Healthcare: Barriers to Access and Care and Evidence-Based Solutions." Healthcare management forum 30, no. 2: 111-116. https://dx.doi.org/10.1177/0840470416679413.

Lee, Sherman A., Amanda A. Mathis, et a1. 2020. "Clinically Significant Fear and Anxiety of Covid-19: A Psychometric Examination of the Coronavirus Anxiety Scale." Psychiatry research 290: 113112-113112. https://dx.doi.org/10.1016/j.psychres.2020.113112.

Lukman, M., T. Suzuki, et al. 2015. "A Study of the Gathering Styles of Indonesian Culture." Journal of Architecture and Planning (transactions of Aij) 80: 999-1008.

Setkab. 2020. "Gov't to Allow Reopening Schools in Green Zones with Several Conditions." Secretary of The State. Accessed 30 September, 2020. Retrieved from: https://setkab.go.id/en/govt-to-allow-reopening-schools-in-green-zones-with-severalconditions/.

Usher, Kim, Navjot Bhullar, et al. 2020. "Family Violence and Covid-19: Increased Vulnerability and Reduced Options for Support." International journal of mental health nursing 29, no. 4: 549-552. https://dx.doi.org/10.1111/inm.12735.

Xiong, Jiaqi, Orly Lipsitz, et al. 2020. "Impact of Covid-19 Pandemic on Mental Health in the General Population: A Systematic Review." Journal of affective disorders 277: 55-64. https://dx.doi.org/10.1016/j.jad.2020.08.001.

Zhang, Hongwei. 2020. "The Influence of the Ongoing Covid-19 Pandemic on Family Violence in China." Journal of family violence: 1-11. https://dx.doi.org/10.1007/s10896-020-00196-8. 